\title{
Spatial and temporal distribution and abundance of two species of Persephona (Decapoda: Brachyura: Leucosiidae) on the southern coast of the state of São Paulo, Brazil
}

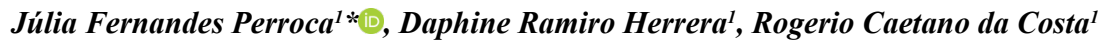 \\ ${ }^{1}$ Universidade Estadual Paulista, Laboratório de Biologia de Camarões Marinhos e de Água Doce, Faculdade \\ de Ciências, Departamento de Ciências Biológicas, Av. Eng. Luiz Edmundo Corrijo Coube, 14-01, Vargem \\ Limpa, 17033-360, Bauru, SP, Brasil \\ *Corresponding author: Júlia Fernandes Perroca, e-mail: juliaperroca@gmail.com
}

PERROCA, J., HERRERA, D., COSTA, R. Spatial and temporal distribution and abundance of two species of Persephona (Decapoda: Brachyura: Leucosiidae) on the southern coast of the state of São Paulo, Brazil. Biota Neotropica. 19(1): e20180534. http://dx.doi.org/10.1590/1676-0611-BN-2018-0534

\begin{abstract}
Crabs of the genus Persephona are intensely captured in shrimp fisheries as bycatch in the Cananéia region off the coast of the state of São Paulo, Brazil. The analysis of the spatial and temporal distribution of Persephona punctata and Persephona mediterranea could provide information about variation in the abundance of these species, as well as the environmental variables affecting their distribution and the existence of a possible habitat partitioning. Using a shrimp fishery boat equipped with double-rig nets, crabs were monthly captured from July 2012 to June 2014 in seven sites: four in the coastal area adjacent to the Cananéia region and three in the Mar Pequeno estuarine area. The abundances of both species were compared according to spatial (among sites) and temporal (years and seasons) scale distribution. A total of 396 individuals of P. punctata and 64 of P. mediterranea were captured. The abundance of both species was higher in the second sampling year (July 2013-June 2014) and in coastal areas; only one individual of each species was captured in the estuarine area due to the low salinity at this location (approximately $27.7 \%$ ). The temperature was the environmental variable that most affected the distribution of both species, which was more abundant in warmer periods. The temporal variation in abundance was modulated by temperature, while salinity modulated the spatial distribution of $P$. punctata and P. mediterranea. The spatial-temporal distribution of both species differered in Cananéia, pointing to a similar use of the environment's resources.

Keywords: Ecological distribution, abiotic factors, Brachyura, habitat partitioning, bycatch.
\end{abstract}

\section{Distribuição espacial e temporal e abundância de duas espécies do gênero Persephona (Decapoda: Brachyura: Leucosiidae) no litoral sul do estado de São Paulo, Brasil}

Resumo: Os caranguejos Persephona são intensamente capturados na pesca do camarão como fauna acompanhante, inclusive na região de Cananéia no litoral do estado de São Paulo, no Brasil. A avaliação da distribuição espaço-temporal pode, consequentemente, fornecer informações sobre variações na abundância de Persephona punctata e Persephona mediterranea, bem como as variáveis ambientais que afetam suas distribuições e uma possível partilha de habitat desses congêneres. Com um barco de pesca de camarão equipado com redes de arrasto duplo, os indivíduos foram coletados mensalmente de julho de 2012 a junho de 2014 em sete locais: quatro na área costeira adjacente à região de Cananéia e três na área estuarina Mar Pequeno. A abundância dessas espécies foi comparada de acordo com a distribuição espacial (entre sítios) bem como entre anos e estações. Um total de 396 indivíduos de $P$. punctata e de 64 de $P$. mediterranea foram capturados. A abundância de ambas as espécies foi maior no segundo ano de coleta (julho de 2013 a junho de 2014). A abundância de ambas as espécies foi maior na área costeira, e apenas um indivíduo de cada espécie foi capturado na área estuarina devido à baixa salinidade neste local (27.7\%o aproximadamente). A temperatura foi o fator ambiental que afetou significativamente a distribuição das espécies, com maiores abundâncias em períodos mais quentes. A variação temporal da abundância foi modulada pela temperatura, enquanto a salinidade modulou a distribuição espacial de $P$. punctata e $P$. mediterranea. Em Cananéia as espécies não apresentaram diferenças na distribuição espaço-temporal, o que nos permite assumir elas habitam a área de uma forma muito similar.

Palavras-chave: Distribuição ecológica, fatores abióticos, braquiúros, partilha de habitat, fauna acompanhante. 


\section{Introduction}

The family Leucosiidae Samouelle, 1819 is commonly found in different abundances along the Brazilian coast. Persephona Leach, 1852 is the most representative genus of the family (Rieger 1999, Bertini et al. 2001), and Persephona mediterranea (Herbst, 1794) and P. punctata (Linnaeus, 1758) are the most common species found in coastal areas of the state of São Paulo (Mantelatto et al. 2016). These crabs are widely distributed in the Atlantic Ocean, from intertidal to subtidal zones at depths of $60 \mathrm{~m}$ and $50 \mathrm{~m}$, respectively, in substrates composed of mud, sand, shells, calcareous algae, and/or corals (Melo 1996). They are frequently captured in shrimp trawling fisheries on the southeast coast of Brazil and, although they are not economically important, their populations are subjected to the same impacts as the commercially exploited crabs and shrimps (Pereira et al. 2014).

Fisheries using non-selective trawls as fishing gear accidentally extract a highly diverse bycatch fauna composed of small or non-commercial individuals that are usually returned to the sea dead or weakened. This activity may lead to a decrease in fishery stocks (Lewison et al. 2004). Considering this scenario, knowing the distribution patterns of organisms captured in trawling fisheries is fundamental to assess possible impacts and contribute to the development of mitigation activities (Carvalho et al. 2010).

There are few studies addressing the biology of the genus Persephona, most of them performed in the Ubatuba region, along the northern coast of the state of São Paulo. Negreiros-Fransozo et al. (1989), described the larval development of P. mediterranea; Bertini et al. (2001) and Pereira et al. (2014) reported the spatial-temporal distribution of three species of Persephona; Bertini et al. (2010) estimated the reproductive period and sexual maturity of $P$. mediterranea in Ubatuba; and Almeida et al. (2013) compared the relative growth, sexual maturity, and reproductive period of three species of the genus. A taxonomic review of the genus was published by Magalhães (2016), and comparative analysis of the distribution and sexual maturity of $P$. lichteinsteiini and P. punctata was performed by Carvalho et al. (2010) on the coast of Ilhéus, state of Bahia.

The two species studied herein have a wide distribution. Persephona mediterranea is found in the eastern Gulf of Mexico, the Caribbean Sea, the Antilles, Venezuela, Suriname, French Guiana, Brazil, and Uruguay (Magalhães et al. 2016). Persephona punctata is distributed in the Carribean Sea, the Antilles, Colombia, Venezuela, Guianas, Suriname, and Brazil (Magalhães et al. 2016). Despite their wide distribution, there are gaps in the knowledge about their ecology and studies in areas with different environmental features are extremely important to assess how environment modulates their distribution and abundance.

The well-conserved Cananéia-Iguape system is considered one of the most important humid areas in the Brazilian coast due to its biodiversity and primary productivity (Mendonça 2007, Leme et al. 2014, Pinheiro et al. 2018). The Federal Environmental Protection Area of Cananéia, Iguape, and Peruíbe - APA-CIP - was established in 1984 aiming at protecting the biological diversity and ensuring the sustainable use of natural resources (Mendonça 2007). The area is located beyond the tropic line and is subjected to a higher climatic variation than systems located within the tropics (Schaefer-Novelli et al. 1990).

An evaluation of the spatial and temporal distribution of $P$. mediterranea and P. punctata in the Cananéia-Iguape system could clarify the variation in the abundance of these congeners and the environmental variables affecting their distribution. This study investigated the habitat partitioning by $P$. mediterranea and P. punctata considering (a) the temporal variation and (b) the spatial variation in their abundances between sampling sites, and (c) the environmental variables affecting their distribution.

\section{Materials and Methods}

\section{Study area}

The Cananéia lagoon estuarine system is located on the southern coast of the state of São Paulo, Brazil $\left(25^{\circ} \mathrm{S}, 48^{\circ} \mathrm{W}\right)$. The system is bordered by the municipality of Iguape to the north, by the Ilha Comprida island to the east, by the Serra do Mar mountains to the west, and by Cananéia and Cardoso Islands to the south. The lagoon has two main connections with the ocean, by a single channel to the north (Mar Pequeno - Barra de Icapara) and by two segments to the south (Mar de Cananéia and Mar de Cubatão - Baía Trapandé), which surround the Cananéia Island (Mendonça \& Katsuragawa 2001). This region is mainly influenced by the tropical water mass brought by the Brazilian Current, Coastal Water, and South Atlantic Central Water (Matsuura 1986). Circulation within the system is primarily driven by the action of tidal waves and fresh water from several rivers (Miyao \& Harari 1989).

Intense artisanal fishing occurs in the Cananéia system and in the adjacent coastal area involving more than 3,000 fishermen from the municipalities of Iguape, Cananéia, and Ilha Comprida (Mendonça \& Katsuragawa 2001).

\section{Sampling}

Crabs were monthly captured from July 2012 to June 2014. Due to adverse environmental conditions in March 2013 and February 2014, no animals were captured in these months. Crabs were captured using a shrimp fishing boat equipped with $10 \mathrm{~m}$ long double-rig nets $(4 \mathrm{~m}$ mouth opening, $20 \mathrm{~mm}$ mesh size, and $18 \mathrm{~mm}$ cod-end).

Seven sampling sites were established and marked using global positioning system coordinates. Four sites were placed in the coastal area adjacent to the Cananéia region: sites 1,2, and 3 located in 10-15 $\mathrm{m}$ isobaths and site 4 located in $5-10 \mathrm{~m}$ isobaths. The other three sampling sites were located in the Mar Pequeno estuarine area (sites 5,6 , and 7) at 5-10 $\mathrm{m}$ isobaths and are influenced by fresh water from the Cananéia-Iguape estuarine complex (Besnard 1950) (Figure 1).

Nets were dragged parallel to the shore for $30 \mathrm{~min}$ in each site, totalling an area of approximately $16,000 \mathrm{~m}^{2}$. After each trawling, crabs were stored in labeled plastic bags and kept frozen until analysis. In the laboratory, individuals were identified to the species level according to Melo (1996).

Water temperature (measured with a mercury thermometer, ${ }^{\circ} \mathrm{C}$ ) and salinity (measured with a specific optical refractometer, \%o) were recorded at all sampling sites. Bottom water samples were obtained with a 5-L Van Dorn bottle. Pluviosity data were taken from the Portal Agrometeorológico e Hidrológico do Estado de São Paulo website (www.ciiagro.org.br).

Sediment samples were collected at each site using a Van Veen grab $\left(0.06 \mathrm{~m}^{2}\right.$ area $)$ to determine the mean sediment grain size $(\phi)$ and organic matter content $(\mathrm{OM})$. In the laboratory, samples were dried in an oven at $70^{\circ} \mathrm{C}$ for $72 \mathrm{~h}$. Grain composition was estimated based on three 


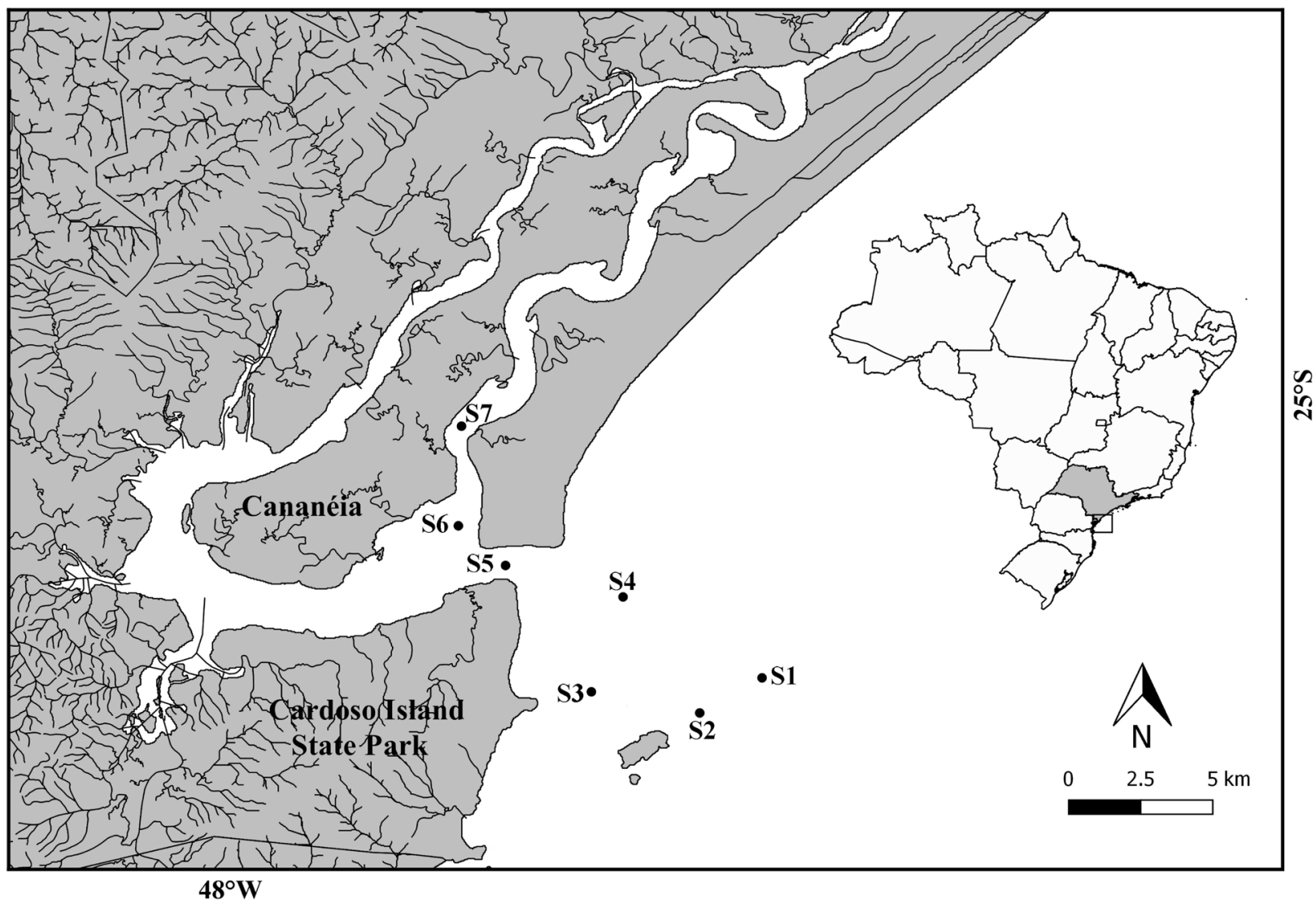

Figure 1. Map showing sampling sites in marine area (S1, S2, S3, S4) and in mar pequeno (S5, S6, S7) in Cananéia.

100 -g subsamples treated with $0.2 \mathrm{~N} \mathrm{NaOH}(250 \mathrm{~mL})$, stirred for $5 \mathrm{~min}$ to separate silt and clay particles, and rinsed using a $0.063 \mathrm{~mm}$ mesh sieve. Sediments were sieved through different mesh sizes to determine the grain size: $2 \mathrm{~mm}$ sieve (gravel), $2.0-1.01 \mathrm{~mm}$ sieve (very coarse sand), $1.0-0.51 \mathrm{~mm}$ sieve (coarse sand), $0.50-0.26 \mathrm{~mm}$ sieve (medium sand), $0.25-0.126$ sieve (fine sand), and $0.125-0.063 \mathrm{~mm}$ sieve (very fine sand). Smaller particles were classified as silt-clay (Tucker 1988).

Grain size categories followed the American standard (Wentworth $1922)$ and fractions were expressed on the phi $(\phi)$ scale to estimate the central tendency of sediment samples. For instance: $-1=\phi<0$ (gravel), $0=\phi<1$ (coarse sand), $1=\phi<2$ (intermediate sand), $2=\phi<3$ (fine sand), $3=\phi<4$ (very fine sand), and $\phi \geq 4$ (silt + clay) (Hakanson $\&$ Jansson 1983, Tucker 1988). Cumulative particle size curves were plotted using the $\phi$ scale with values corresponding to the $16^{\text {th }}, 50^{\text {th }}$, and $84^{\text {th }}$ percentiles used to determine the mean diameter of sediment via the formula:

$$
\mathrm{Md}=\left(\phi_{16}+\phi_{50}+\phi_{84}\right) / 3
$$

Finally, $\phi$ was calculated using the formula $\phi=\log _{2} d$, where $d$ is the grain diameter (mm) (Tucker 1988).

To estimate the OM content, oven dried sediment samples (10 g) from each site were placed in porcelain crucibles, and heated in an oven at $500^{\circ} \mathrm{C}$ for $3 \mathrm{~h}$. The percentage of organic matter was estimated as the difference between the initial and final crucible weight (Mantelatto \& Fransozo 1999).

\section{Statistical analysis}

Data were tested for homoscedasticity (Levene test) and normality (Shapiro-Wilk test) as a pre-requisite for the statistical analysis (Zar 1999). The abundance of Persephona mediterranea and Persephona punctata were analysed separately and compared considering their spatial and temporal distribution. The spatial distribution (between sites) was evaluated using an Analysis of Variance (one-way ANOVA) and a post-hoc Tukey test ( $\alpha=5 \%$ ) and the temporal distribution (years and seasons) was evaluated using a nested ANOVA and a post-hoc Tukey test $(\alpha=5 \%)$. For statistical purposes, seasons were grouped as follows: summer $=$ January-March, autumn $=$ April-June, winter $=$ July-September, and spring = October-December. When necessary, the data were logarithmized to satisfy the analyses' premises (Zar 1999). Catch-per-unit-of-effort (CPUE) was calculated for each species and expressed on numbers of individuals per hour of trawling (ind $/ h$ ).

A canonical redundancy analysis (RDA) was performed to assess the influence of variation in environmental variables (bottom water temperature and salinity, phi and organic matter content) on the monthly data of the species abundance using R (R Development Core Team 2013), considering $\alpha=5 \%$ (Zar 1999). The statistical package "vegan" was used (RDA, “envifit” Oksanen et al. 2013). 
A time series analysis was performed (Cross Correlation Statistica 7.0, Statsoft, Inc) ( $\alpha=5 \%$ ) (Statsoft 2004) to investigate the relationships between environmental variables (temperature, salinity, sediment texture, and percentage of organic matter in the sediment) and species abundance. In a cross-correlation analysis, two data series were compared as a function of a time lag (n), using the Pearson correlation coefficient to measure the relationship between values of the first and second data series $n$ months earlier (in negative lags) or later (in positive lags), and at lag 0 . The correlation coefficient values are equivalent to the standard Pearson correlation (Legentil et al. 2013).

An exploratory data analysis was also performed to establish classes of environmental variables and calculate the frequency of crabs in these classes.

\section{Results}

\section{Environmental variables}

The bottom water temperature (BT) ranged from $17.2-29.8^{\circ} \mathrm{C}$ (mean: $23.1^{\circ} \mathrm{C} \pm 3.1$ ). The highest mean BT was recorded in January $2014\left(28.9^{\circ} \mathrm{C} \pm 0.86\right)$ and the lowest mean BT occurred in July 2013 $\left(17.5^{\circ} \mathrm{C} \pm 0.31\right)$ (Figure $\left.2 \mathrm{~A}\right)$. The highest spatial mean BT variation was recorded in sites 5, 6, and 7 (Figure 2B).

Bottom water salinity (BS) ranged from 16.9-38\% (mean: 31.4\%o $\pm 5)$. The highest mean BS was recorded in October $2012(36.1 \% \pm \pm$ $2.38)$ and the lowest in November $2013(25.7 \%$ 土 4.07) (Figure 2C). Spatially, the lowest and the highest mean salinity were recorded in sites 7 and 1, respectively (Figure 2D).

Sediment samples were mainly composed of very fine sand $(3 \phi<$ 4). Exceptions were recorded in site 4 (silt and clay; $\phi \geq 4$ ) and site 6 (fine sand; $2 \phi<3$ ) (Figure 3). The highest percentage of organic matter was found in site 4 (6.56\%) and the lowest in site 6 (2.07\%) (Figure 3).

The highest mean pluviosity in the study area was recorded in March $2013(48.9 \mathrm{~mm} \pm 30.8)$ and the lowest in August $2012(2.2 \mathrm{~mm}$ \pm 4 ) (Figure 4).

\section{Temporal and spatial distribution}

A total of 460 crabs were captured (64 P. mediterranea individuals and 396 P. punctata individuals). During the first year of sampling, 2.29 $\mathrm{ind} / \mathrm{h}$ of $P$. mediterranea and $15.43 \mathrm{ind} / \mathrm{h}$ of $P$. punctata were captured (Figure 5). In the second year, these numbers increased to $16 \mathrm{ind} / \mathrm{h}$ of P. mediterranea and $97.71 \mathrm{ind} / \mathrm{h}$ of $P$. punctata (Figure 5). The highest abundances of $P$. mediterranea $(3.57 \mathrm{ind} / \mathrm{h} ; 39 \%)$ and $P$. punctata $(63.14$ ind/h; 56\%) occurred in January 2014 (Figure 5). In both years, the abundance of $P$. punctata was not significantly different considering the temporal scales $(\mathrm{p}>0.05)$. As for $P$. mediterranea, the abundance was different when the year was considered ( $1 \mathrm{df}, \mathrm{F}=5.17, \mathrm{p}=0.03$ ).

Spatially, more crabs were sampled in site $1,3.18 \mathrm{ind} / \mathrm{h}$ of $P$. mediterranea and $18.55 \mathrm{ind} / \mathrm{h}$ of $P$. punctata (Figure 6 ). There was a significant difference in the abundance of both species depending on the site. Persephona punctata was more abundant in sites 1 and 2 than in sites 5, 6, and 7 (one-way ANOVA, $6 \mathrm{df}, \mathrm{F}=6.02, \mathrm{p}=0.000013$; Tukey Test $\mathrm{p}<0.05)$. Persephona mediterranea was more abundant in site 1 than in sites 2, 5, 6 and 7 (one-way ANOVA, $6 \mathrm{df}, \mathrm{F}=4.38$, $\mathrm{p}$ $=0.000435$; Tukey Test $\mathrm{p}<0.05)$. No crabs were captured in sites 6 and 7 (Figure 6).

\section{Abundance vs. environmental variables}

According to the RDA analysis, only bottom temperature was significantly correlated with the abundance of both species (Table 1); the first axis of the biplot chart explained $99 \%$ of the total variance $\left(\right.$ RDA, $\left.\mathrm{r}^{2} 0.0393, \mathrm{p}=0.044\right)$.

Persephona punctata and $P$. mediterranea were more abundant at higher temperatures $\left(27-29^{\circ} \mathrm{C}\right)$, higher salinities $(>34 \%$ o), in sites with sediment composed of very fine sand rich in silt and clay fractions $(\phi$ $>4$ ), and with organic matter concentrations lower than $9 \%$ (Figure 7 , Figure 8). The highest abundance of both species was found in site 1, which is predominantly composed of very fine sand; silt and clay were also present in this site and varied according to the sampling month. As a result, the cross-correlation showed no significant correlation between environmental variables and abundance (Time series, $\mathrm{p}>0.05$ ).

\section{Discussion}

The water temperature along the coast of Cananéia varied as expected for subtropical regions, with higher temperatures in summer and lower temperatures in winter. This variation determined the fluctuations in P. punctata and P. mediterranea abundance throughout the year; e.g. in January 2014, BT and abundance were the highest for both species.

Bertini et al. (2001) and Pereira et al. (2014), also found a higher abundance of these species in periods of high temperatures in surveys along the northern coast of the Ubatuba region (São Paulo). Both studies indicated the highest crab abundances in autumn and winter when temperatures were higher than in spring and summer. This temperature difference is linked to the influence of the South Atlantic Central Water (SACW) in the Ubatuba region during spring and summer, which decreases the water temperature. However, in Cananéia, differences in abundance were seen mainly between summer and autumn. The lowest temperatures were recorded during winter and autumn, limiting the capture of both species.

Higher temperatures act on energy demanding events, such as moulting and spawning, play an important role in triggering reproductive events, and favour high abundances of individuals (Stelle \& Bert 1994). The seasonal nature of moulting can be influenced by temporal variation in temperature and adequate food availability (Aiken 1969). This relationship was confirmed in the Cananéia region by Garcia et al. (2018) that found a positive correlation between the monthly temperature variation and chlorophyll- $a$ concentration.

Coastal waters are subjected to a higher variation in salinity due to freshwater inflow and this may influence the species distribution (Carvalho et al. 2010). Miyao et al. (1986), classified the salinity in the Cananéia estuary as partially mixed, increasing according to depth. This explains the higher abundance of crabs recorded in site $1(10-15 \mathrm{~m})$ in comparison with site $5(5-10 \mathrm{~m})$, which is located in the estuarine region. Sites 6 and 7 are located in a region called Mar Pequeno, which is shallower and influenced by continental waters, resulting in a lower salinity when compared with marine coastal areas. Garcia et al. (2018), characterized this area as a mesohaline estuary, with salinity near to $15 \%$. No crabs were captured in sites 6 and 7, demonstrating that $P$. punctata and P. mediterranea do not inhabit sites with low salinity, corroborating features of their larval development which 

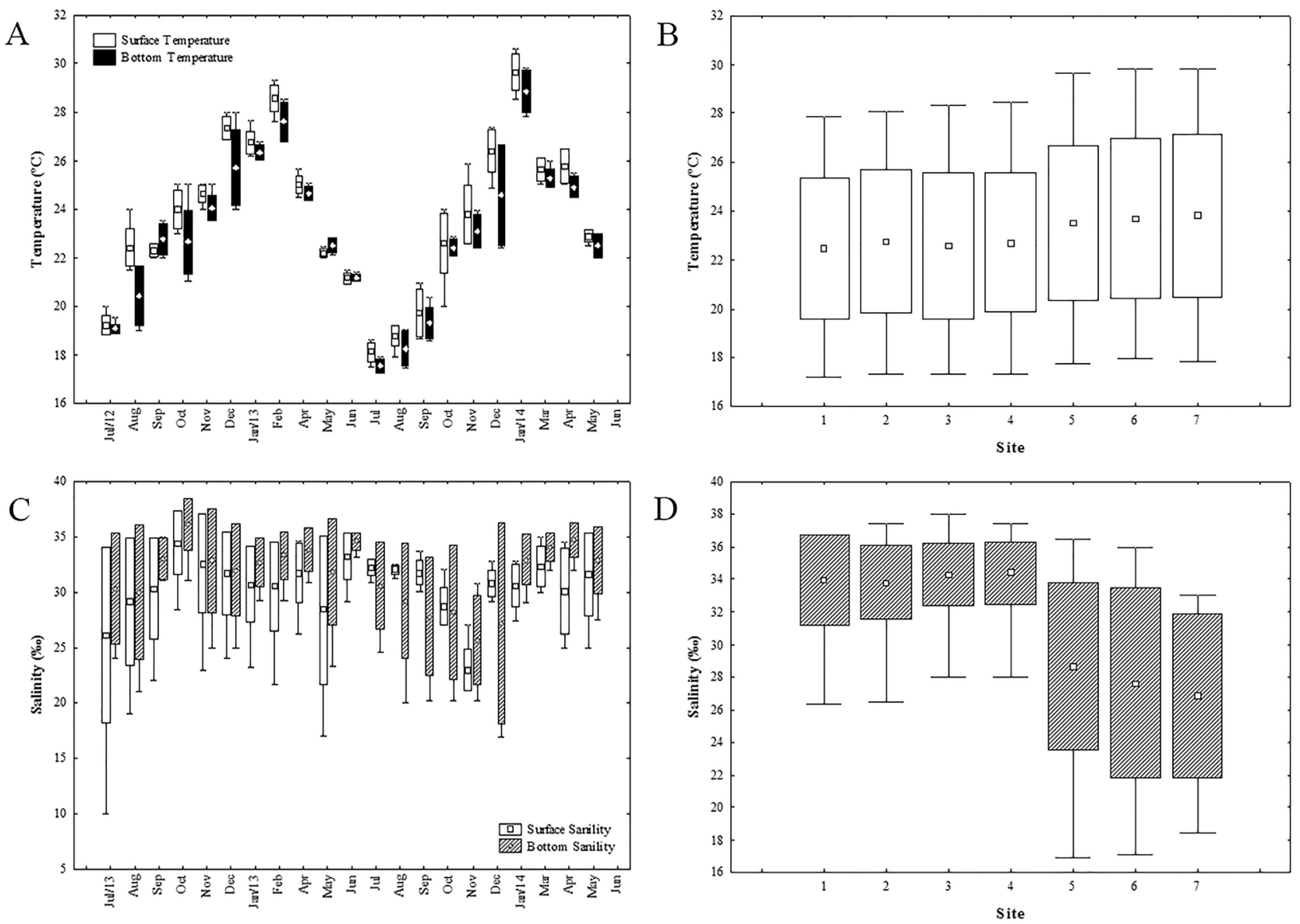

Figure 2. [A] monthly variation of mean values of surface (S) and bottom (F) water temperature; $[B]$ Mean values and minimum and maximum amplitudes of bottom water temperature; [C] Monthly variation of mean values of surface (S) and bottom (F) water salinity; [D] Mean values and minimum and maximum amplitudes of bottom water salinity. Abiotic factors were sampled from July/12 to May/14 in Cananéia region. (Mean; SD = standard deviation; Min = minimum; Max $=$ maximum)

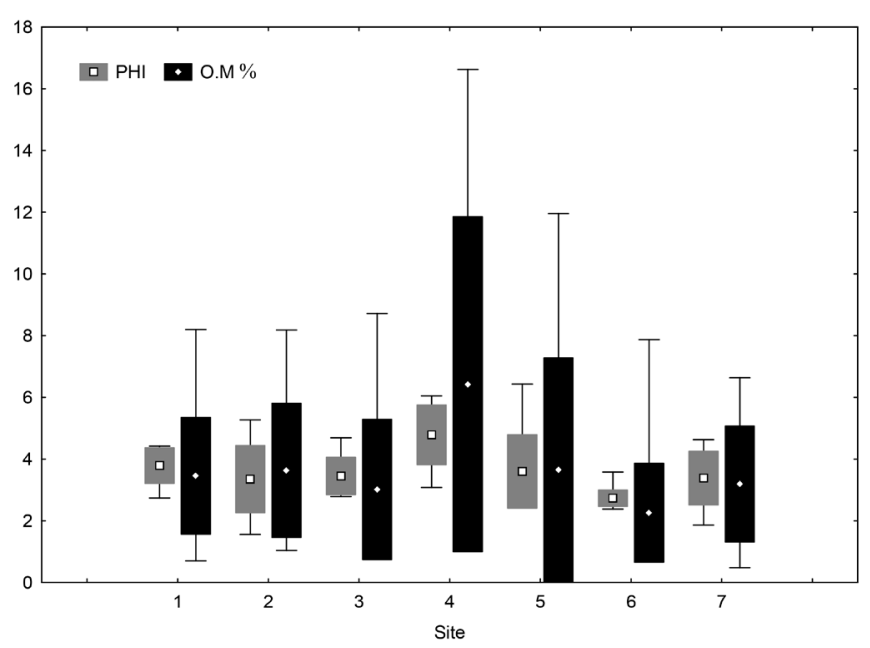

Figure 3. Mean values and minimum and maximum amplitudes of grain size (PHI) and organic matter content (O.M \%), sampled from July/12 to May/14 in Cananéia region. (Mean; $\mathrm{SD}=$ standard deviation; Min = minimum; $\mathrm{Max}=$ maximum).

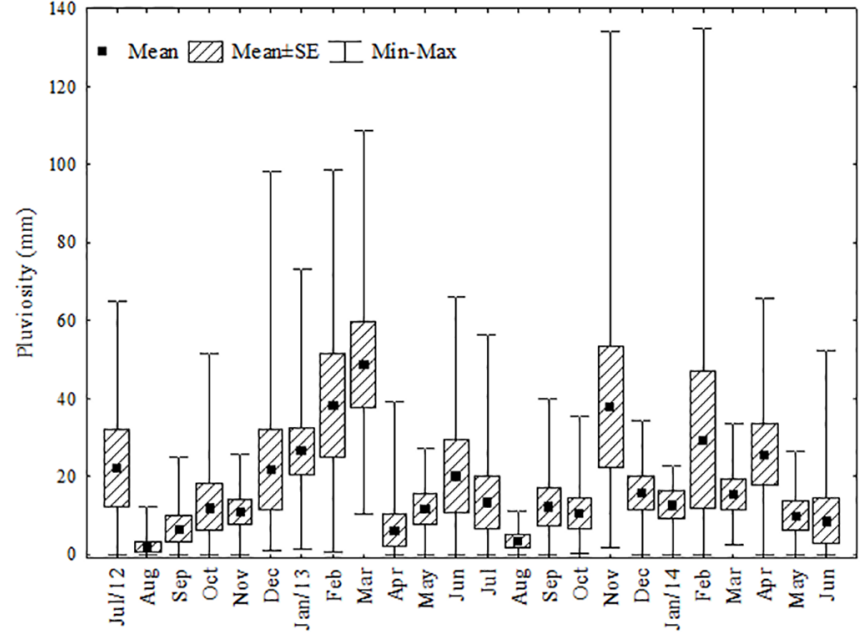

Figure 4. Mean values and minimum and maximum amplitudes of pluviosity (mm) sampled from July/12 to May/14 in Cananéia region. (Mean; SD = standard deviation; $\operatorname{Min}=$ minimum; $\operatorname{Max}=$ maximum). 
Perroca, J.F. et al.

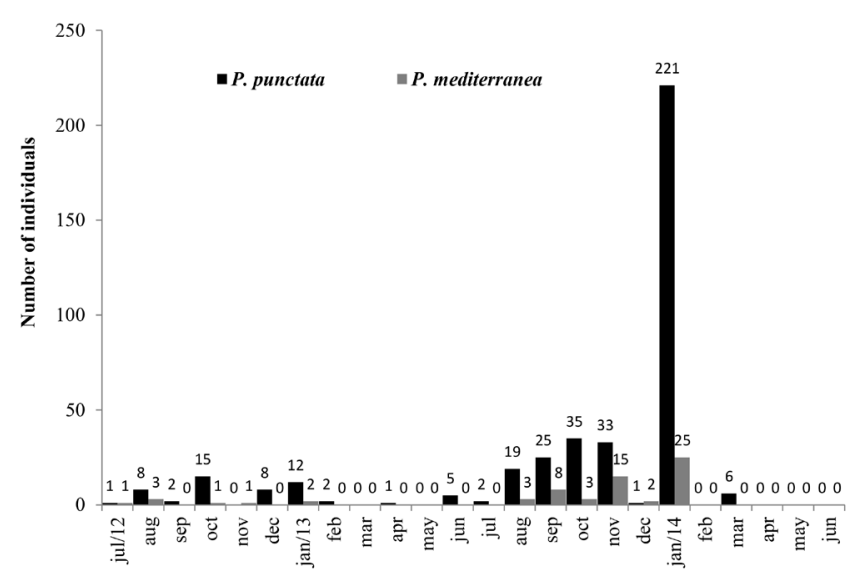

Figure 5. Number of individuals of Persephona punctata (Linnaeus, 1758) and Persephona mediterranea (Herbst, 1794) per month in Cananéia/SP, from July/12 to June/14.

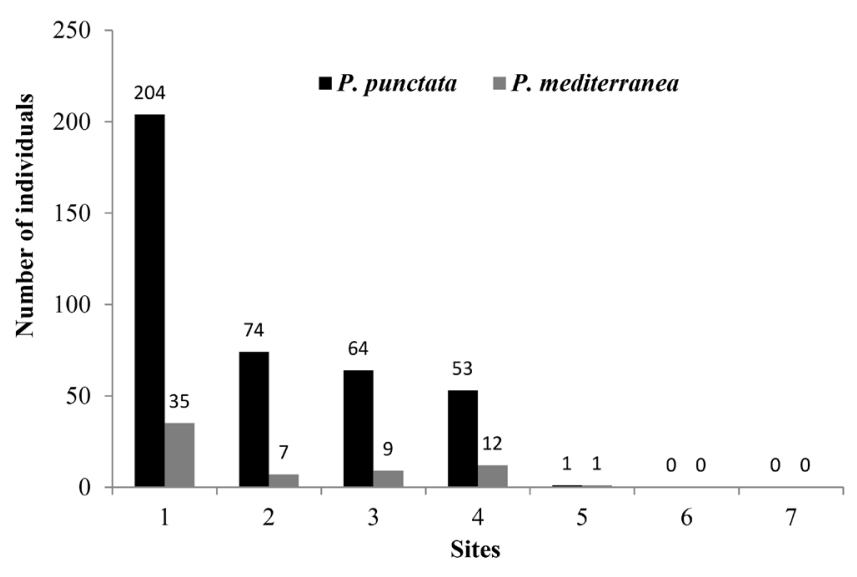

Figure 6. Number of individuals of Persephona punctata (Linnaeus, 1758) and Persephona mediterranea (Herbst, 1794) per site in Cananéia/SP, from July/12 to June/14.

Table 1. Results from Redundancy Analysis (RDA) among abundances of Persephona mediterranea (Herbst, 1794) and Persephona punctata (Linnaeus, 1758) and environmental factors, sampled in Cananéia region, São Paulo State, from July 2012 to June 2014. Species Score (RDA1) P. mediterranea $=0.1958$ and P. punctata $=2.2951$.

\begin{tabular}{ccccccc}
\hline Explained proportion & Environmental factors & RDA1 & RDA2 & $\mathbf{r}^{\mathbf{2}}$ & \multicolumn{1}{c}{ P } \\
\hline RDA1 & 0.9985 & BT & 0.95987 & 0.28043 & 0.0393 & $0.044^{*}$ \\
RDA2 & 0.00152 & BS & 0.98540 & 0.17024 & 0.0078 & 0.568 \\
& & Phi & -0.04175 & -0.99913 & 0.0089 & 0.126 \\
& & OM & 0.99959 & 0.02850 & 0.0100 & 0.414 \\
\hline
\end{tabular}

$*=\mathrm{P}<0,05 . \mathrm{BT}-$ bottom temperature, $\mathrm{BS}-$ bottom salinity, Phi - granulometric fraction, $\mathrm{OM}$ - organic matter content.
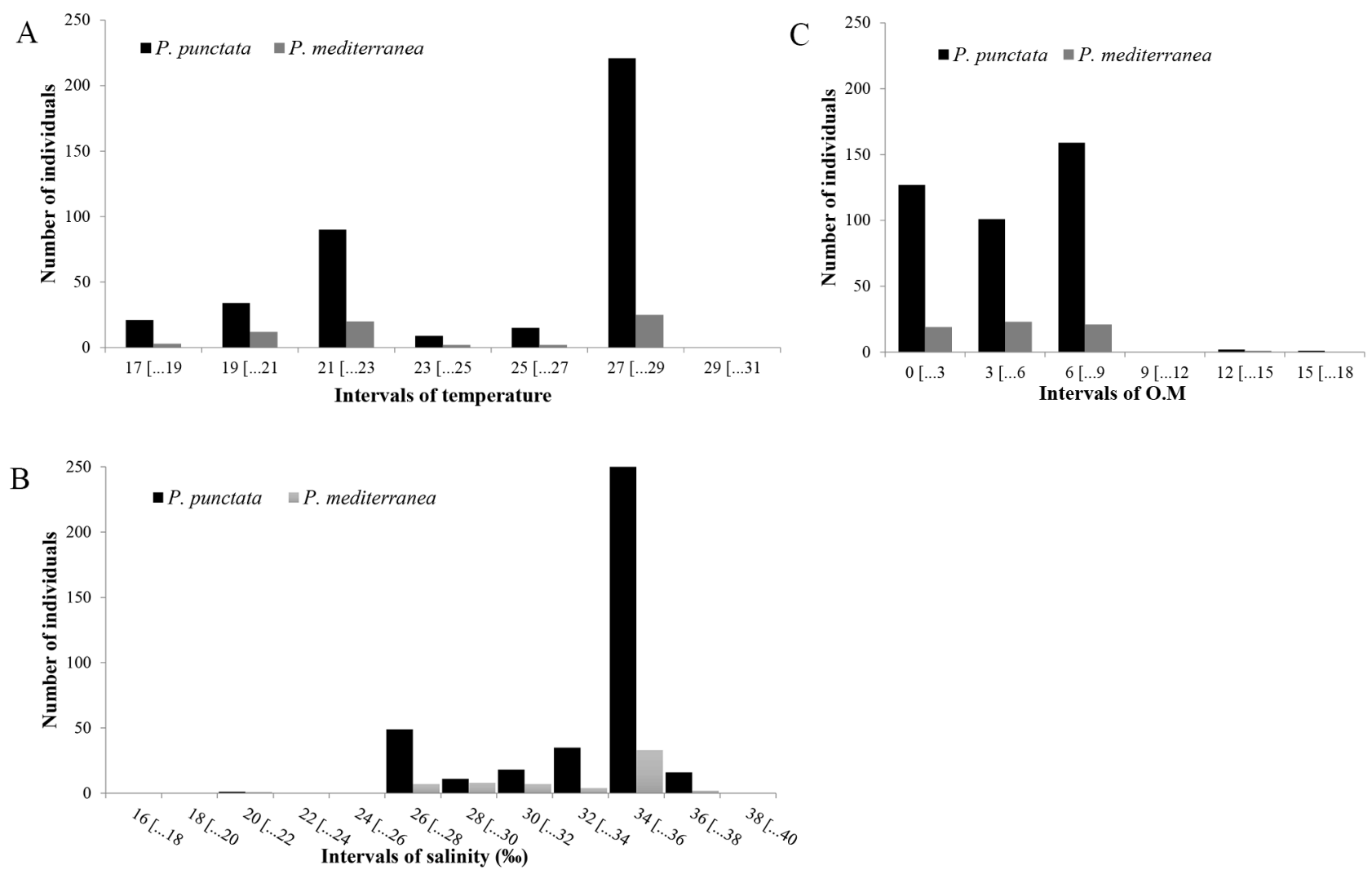

Figure 7. Number of individuals of Persephona punctata (Linnaeus, 1758) and Persephona mediterranea (Herbst, 1794) by intervals of abiotic factors: [A] temperature; [B] salinity; [C] organic matter content (O.M). All data was sampled from July/12 to June/14 in Cananéia region. 


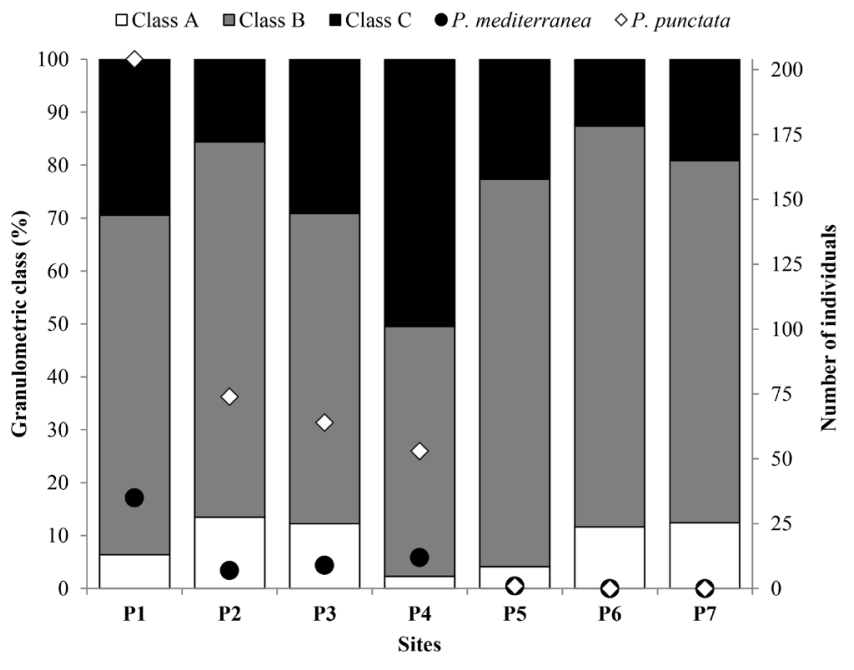

Figure 8. Grain size categories and number of individuals of Persephona punctata (Linnaeus, 1758) and Persephona mediterranea (Herbst, 1794) by site. [Class A] gravel, coarse sand and intermediate sand; [Class B] fine sand and very fine sand; [Class C] silt and clay. All data was sampled from July/12 to June/14 in Cananéia region.

occurs in inshore and offshore areas with increased salinity (34/35 \%o) (Negreiros-Fransozo et al. 1989, Hirose 2009).

Carvalho et al. (2010), evaluating populations of $P$. punctata and $P$. lichteinsteinii in Ilhéus, Bahia, found that individuals were more abundant in autumn when salinity was reduced to an average of $35 \%$. In our survey, we found that both species were more abundant in areas with a salinity range of $32-34 \%$, which is considered high for the region since the study area is strongly influenced by fresh waters. During the first year, higher crab abundances were recorded in spring; abundance might have decreased in summer due to the higher pluviosity during this period, which consequently lowered the salinity. In the second year, pluviosity was higher in spring and salinity was correspondingly lower during this season. In the following summer, pluviosity decreased and salinity increased, and the abundance of both species increased. Nevertheless, Garcia et al (2018), did not found a correlation between salinity and pluviosity in Cananéia, probably because after the construction of the Valo Grande channel in 1852 (GEOBRÁS 1966) salinity is controlled by the water input from the Ribeira Iguape River. Tidal influx might also have influenced these results since the Cananéia strait is located in the southern portion of the Cananéia system and do not have significant barriers between the region and the ocean.

Sediment granulometry did not have a significant influence on the species distribution, both species often inhabit sites composed mainly of very fine sand, as seen in site 1 . However, the seasonal variation in abundance demonstrated that when more silt and clay were present, species abundance also increased. Bertini et al. (2001) and Pereira et al. (2014), reported that both $P$. punctata and $P$. mediterranea inhabit sites with sediment composed of silt and clay in the Ubatuba region; these substrate types allow crabs to bury themselves for protection and food foraging, results that were corroborated by our observations.

Considering that the substrate in site 4 is mainly composed of silt and clay, which retain more organic particles, it is clear why the percentage of organic matter content in site was the highest (Castilho et al. 2008). The organic matter was not directly related to the abundance of $P$. punctata and P. mediterranea, but it influences the abundance of Polychaeta which is used as a food resource by both species (Petti et al. 1996).

Marine crustaceans often vigorously defend shelter and food resources, and similar-sized crabs fight more intensely for these resources (Dingle 1983, Huntinford et al. 1995). Historically, biologists have postulated that competition should be more intense between species more closely related phylogenetically (Elton \& Miller 1954). Other authors, however, have reported that the competition pressure may be reduced when organisms use strategies that allow them to exploit the same niche in different ways (Peterson \& Andre 1980, Evans 1983, Abrams 1986, 1990). This is common in coastal lagoons, estuaries, and shallow marine environments due to the abundance of resources and the high diversity of species colonising these habitats (González-Gurriaran et al. 1989).

In Cananéia, $P$. punctata and $P$. mediterranea inhabit the same area and lack differences in spatial and temporal distribution, suggesting that they have the same requirements regarding environmental variables. This probably occurs because shallow areas (sites 6 and 7) have very low salinity, which hinder the occurrence of P. punctata and P. mediterranea. Furthermore, habitat partitioning does not necessarily mean a diet overlap. Rosas et al. (1994), found that the feeding habits of three coexisting species of Callinectes varied seasonally, suggesting that the variation is more related to the differences in the energy requirements of each species than to the abundance of prey. This is probably the reason why, although $P$. punctata is more abundant than $P$. mediterranea, both species are coexisting in the same habitat. Dominance among crabs could have a proximal cause based on behavioural interactions, and behavioural hierarchies should be considered when considering explanations for co-occurrence and distribution of crabs (Brown et al. 2005).

Overall, the present study showed that increased temperatures determined the temporal variation in abundance, and salinity modulated the spatial distribution of $P$. punctata and $P$. mediterranea, limiting these crabs to the marine area. The Cananéia-Iguape System has very distinctive oceanographic features and our study contributed with information about ecological aspects of both species, which have been rarely studied despite their wide distribution.

Future studies about population structure, reproductive period, and sexual maturity are essential to better understand the factors driving the biology of these species. Studies considering the species distribution in different latitudes would be crucial to understand the life history patterns of P. punctata and P. mediterranea.

\section{Aknowledgements}

We are grateful to the staff of the Laboratório de Camarões Marinhos e de Água Doce (LABCAM) and the Núcleo de Estudos em Biologia, Ecologia e Cultivo de Crustáceos (NEBECC) for assistance in fieldwork. This work was supported by the São Paulo Research Foundation - FAPESP under Grant 2014/27210-8 (Scholarship) and Grant 2010/50188-8 (Thematic Biota). We are also thankful to the Editor and reviewers' contributions to the improvement of our manuscript. 


\section{Author Contributions}

Júlia Fernandes Perroca: The manuscript was an undergraduate research project of the author.

Daphine Ramiro Herrera: contributed to the definition of statistical analyzes and the interpretation of results and discussion.

Rogerio Caetano da Costa: contributed to the methodological design and assisted in the interpretation of the results and the discussion.

\section{Conflicts of interest}

The authors declare that have no conflict of interest related to the publication of this manuscript.

\section{References}

ABRAMS, P.A. 1986. Character displacement and niche shift analyzed using consuming-resource models of competition. Theor Popul Biol. 29:107-160

ABRAMS, P.A. 1990. Ecological vs. evolutionary consequences of competition. Oikos. 57:147-151.

AIKEN, D.E. 1969. Photoperiod, endocrinology and the Crustacean molt cycle. Science. 164: 149-155.

ALMEIDA, A.C., HIYODO, C., COBO, V.J., BERTINI, G., FRANSOZO, V. \& TEIXEIRA, G. 2013. Relative growth, sexual maturity, and breeding season of three species of the genus Persephona (Decapoda: Brachyura:Leucosiidae): a comparative study. J Mar Biol Assoc UK 93(6):1581-1591.

BERTINI, G., FRANSOZO, A. \& COSTA, R.C. 2001. Ecological distribution of three species of Persephona (Brachyura, Leucosiidae) in the Ubatuba region, São Paulo, Brazil. Nauplius. 9(1):31-41.

BERTINI, G. \& FRANSOZO, A. 2004. Bathymetric distribution of brachyuran crab (Crustacea, Decapoda) communities on coastal soft bottoms off southeastern Brazil. Mar Ecol Prog Ser. 279:193-200.

BERTINI, G., TEIXEIRA, G.M., FRANSOZO, V. \& FRANSOZO, A. 2010. Reproductive events and size at the onset of sexual maturity of mottled purse crab, Persephona mediterranea (Herbst, 1794) (Brachyura, Leucosioidea) on the southeastern Brazilian coast. Int J Inver Rep Dev. 54(1):7-17.

BESNARD, W. 1950. Considerações gerais em torno da região lagunar de Cananéia-Iguape. Bolm Inst Oceanog. 1(1): 19 pages.

BROWN, K.M., KEENAN, S.F. \& BANKS, P.D. 2005. Dominance hierarchies in xanthid crabs: roles in resource-holding potential and field distributions. Mar Ecol Prog Ser. 291: 189-196.

CARVALHO, F.L., SOUZA-CARVALHO, E.A \& COUTO, E.C.G. 2010 Comparative analysis of the distribution and morphological sexual maturity of Persephona lichtensteinii and P. punctata (Brachyura, Leucosiidae) in Ilhéus, BA, Brazil. Nauplius. 18(2):109-115.

CASTILHO, A.L., FURLAN, M., COSTA, R.C \& FRANSOZO, V. 2008. Abundance and temporal-spatial distribution of the rock shrimp Sycionia dorsalis Kingsley, 1878 (Decapoda, Penaeoidea) from the northern coast of São Paulo state, Brazil. Senck Marit. 38(1):75-83.

COSTA, R.C., FRANSOZO, A \& NEGREIROS-FRANSOZO, M.L. 2005. Ecology of the rock shrimp Sicyonia dorsalis Kingsley, 1878 (Crustacea: Sicyoniidae) in a subtropical region of Brazil. Gulf Caribb Res. 17:49-56.

DIEGUES, A.C. 1987. Conservação e desenvolvimento sustentado de ecossistemas litorâneos no Brasil. Secretaria do Meio Ambiente de São Paulo.

DINGLE, H. 1983. Strategies of agonistic behavior in Crustacea. In: Rebach S, Dunham D (eds) Studies in adaptation, the behavior of higher Crustacea. John Wiley \& Sons, New York, p 85-111

ELTON, C.S \& MILLER, R.S. 1954. The Ecological Survey of Animal Communities: With a Practical System of Classifying Habitats by Structural Characters. J Ecol. 42(2):460-496.

EVANS, S. 1983. Production, predation and food niche segregation in a marine shallow soft-bottom community. Mar Ecol Prog Ser. 10:147-157.
GEOBRÁS. 1966. Complexo Valo Grande, Mar Pequeno, Rio Ribeira de Iguape. Relatório para o serviço do Vale do Ribeira - São Paulo: DAEE, v. 1, 448 pages.

GONZÁLEZ-GURRIARÁN, E., FREIRE, J., FERNÁNDEZ, L. \& POZA, E. 1989. Incidencia del cultivo de mejillón em la dieta de Liocarcinus depurator (L.) (Brachyura: Portunidae) em la Ría de Arousa (Galicia, NW España). Cah Biol Mar. 30:307-319.

HAKANSON, L., JANSSON, M., 1983. Principles of Lake Sedimentology. Springer-Verlag, Berlin, Heidelberg, New York, Tokyo.

HEBLING, N.J., MANTELATTO, F.L.M., NEGREIROS-FRANSOZO, M.L \& FRANSOZO, A. 1994. Levantamento e distribuição de braquiúros e anomuros (Crustacea: Decapoda) dos sedimentos sublitorais da região da Ilha Anchieta, Ubatuba (SP). Bolm Inst Pesca. 21:1-9.

HIROSE, G.L. 2009. Distribuição larval planctônica de Brachyura (Crustacea, Decapoda) na região de Ubatuba, com novas descrições larvais para o gênero Persephona Leach, 1817. Phd thesis, Botucatu.

HUNTINGFORD, F.A., SMITH, I.P. \& THORPE, K.E. 1995. Behavioral and physiological studies of aggression in swimming crabs. J Exp Mar Biol Ecol. 193:21-39.

LEGENTIL, S.L., ERWIN, P.M., VELASCO, M. \& TURON, X. 2013. Growing or reproducing in a temperate sea: optimization of resource allocation in a colonial ascidian. Invertebr Biol. 132(1): 69-80.

LEME, M.H.A., SOARES, V.S \& PINHEIRO, M.A.A. 2014. Population dynamics of the mangrove tree crab Aratus pisonii (Brachyura: Sesarmidae) in the estuarine complex of Cananéia-Iguape, São Paulo, Brazil. Panam J Aquat Sci. 9(4):259-266.

LEWISON, R.L., CROWDER, L.B., READ, A.J \& FREEMAN, S.A. 2004 Understanding impacts of fisheries bycatch on marine megafauna. TrendS Ecol Evol. 19(11): 598-604.

MAGALHÃES, T., ROBLES, R., FELDER, D.L \& MANTELATTO, F.L.M. 2016. Integrative Taxonomic Study of the Purse Crab Genus Persephona Leach, 1817 (Brachyura: Leucosiidae): Combining Morphology and Molecular Data. PLoS ONE. 11(4): e0152627. 34 pages.

MANTELATTO, F.L.M \& FRANSOZO, A. 1999. Characterization of the physical and chemical parameters of Ubatuba Bay, northern coast of São Paulo State, Brazil. Revs Brasil Biol. 59(1): 23-31.

MANTELATTO, F.L., BERNARDO, C.H., SILVA, T.E., BERNARDES, V.P., COBO, V.J \& FRANSOZO, A. 2016. Composição e distribuição de crustáceos decápodes associados à pesca do camarão-sete-barbas Xiphopenaeus kroyeri (Heller, 1862) no litoral norte do Estado de São Paulo. Bolm Inst Pesca (Impresso). 42:307-326.

MATSUURA, Y. 1986. Contribuição ao estudo da estrutura oceanográfica da região sudeste entre Cabo Frio (RJ) e Cabo de Santa Marta Grande (SC). Ci e Cult. 38(8):1439-1450.

MELO, G.A.S. 1996. Manual de identificação dos Brachyura (caranguejos e siris) do litoral brasileiro. São Paulo: Editorial Plêiade.

MENDONÇA, J.T \& KATSURAGAWA, M. 2001. Caracterização da pesca artesanal no complexo estuarino-lagunar de Cananéia-Iguape, Estado de São Paulo, Brasil (1995-1996). Acta Sci. 23(2):535-547.

MENDONÇA, J.T. 2007. Gestão dos recursos pesqueiros do complexo estuarino-lagunar de Cananéia-Iguape-Ilha Comprida, litoral sul de São Paulo, Brasil. Phd thesis, Federal University of São Carlos.

MIYAO, S.Y \& HARARI, J. 1989. Estudo preliminar da maré e das correntes de maré da região estuarina de Cananéia $\left(25^{\circ} \mathrm{S}-48^{\circ} \mathrm{W}\right)$. Bolm Inst Ocean. 37(2): 107-123

MIYAO, S.Y., NISHIRARA, L \& SARTI, C.C. 1986. Características físicas e químicas do sistema estuarino-lagunar de Cananéia-Iguape. Bolm Inst Ocean. 34:23-26.

NEGREIROS-FRANSOZO, M.L., FRANSOZO, A \& HEBLING, N.J. 1989. Larval development of Persephona mediterranea (Herbst, 1794) (Brachyura, Leucosiidae) under laboratory conditions. Crustaceana. 57(2):177-193.

OKSANEN, J., BLANCHET, F.G., KINDT, R., LEGENDRE, P., MINCHIN, P.R., O'HARA, R.B., SIMPSON, G.L., SOLYMOS, P., STEVENS, M.H.H. \& WAGNER, H. 2013. Vegan: community ecology package. R Package Version 2: 1-17. 
PEREIRA, R.T., TEIXEIRA, G.M., BERTINI, G., LIMA, P.A., ALENCAR, C.E.R.D \& FRANSOZO, V. 2014. Environmental factors influencing the distribution of three species within the genus Persephona Leach, 1817 (Crustacea, Decapoda, Leucosiidae) in two regions on the northern coast of São Paulo State, Brazil. Lat Am J Aquat Res. 42(2):307-321.

PETERSON, C.H \& ANDRES, S.V. 1980. An experimental analysis of interspecific competition among marine filter feeders in a soft-sediment environment. Ecology 61:129-139.

PETTI, M.A.V., NONATO, E.F \& PAIVA, P.C. 1996. Trophic relationships between polychaetes and brachyuran crabs on the southeastern Brazilian coast. Rev Bras Oceanogr. 44(1):61-67.

PINHEIRO, M.A.A., SOUZA, M.R., SANTOS, L.C.M \& FONTES, R.F.C. 2018. Density, abundance and extractive potential of the mangrove crab, Ucides cordatus (Linnaeus, 1763) (Brachyura, Ocypodidae): subsidies for fishery management. An Acad Bra Cien. 90(2): 1381-1395.

RIEGER, P.J., GIRALDI, J \& VEIGA, C.C. 1999. Persephona lichtensteinii Leach, 1819. Novo registro de Brachyura (Decapoda, Leucossidae), para o litoral de Santa Catarina. Nauplius. 7:193-195.
ROSAS, C., LAZARO-CHAVEZ, E \& BUCKLE-RAMIREZ, F. 1994. Feeding habits and food niche segregation of Callinectes sapidus, C. rathbunae, and C. similis in a subtropical coastal lagoon of the Gulf of Mexico. J Crustacean Biol. 14(2):371-382.

SCHAEFFER-NOVELLI, Y., MESQUITA, H.S.L. \& CINTRON-MOLERO, G. 1990. The Cananéia Lagoon Estuarine System, São Paulo, Brazil. Estuaries. 13(2):193-203.

STATSOFT, Inc. 2004. STATISTICA (data analysis software system), version 7. www.statsoft.com. Computer program.

STEELE, P. \& BERT, T.M. 1994. Population ecology of the blue crab, Callinectes sapidus Rathbun, in a subtropical estuary: population structure, aspects of reproduction, and habitat partitioning. Mar Res Pub. 51: 1-24.

TUCKER, M. 1998. Techniques in sedimentology. Oxford: Blackwell, Blackwell Scientific Publications, Boston.4

WENTWORTH, C.K. 1999. A scale of grade and terms of cladistic sediments. J Geol. 30:377-392.

ZAR, J.H. 1999. Biostatistical Analysis. 2nd edition. Prentice-Hall, New Jersey.

Received: $25 / 02 / 2018$

Revised: 03/11/2018

Accepted: 06/11/2018

Published online: 13/12/2018 